\title{
Framing Electric Mobility for Urban Sustainability in a Circular Economy Context: An Overview of the Literature
}

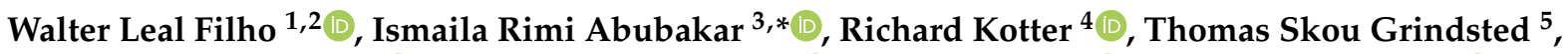

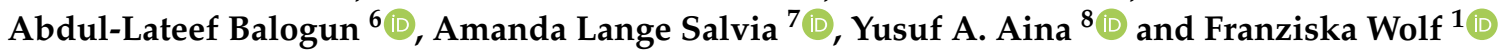

1 Research and Transfer Centre "Sustainable Development and Climate Change Management", European School of Sustainability Science and Research, Faculty of Life Sciences, Hamburg University of Applied Sciences, 21033 Hamburg, Germany; walter.leal2@haw-hamburg.de (W.L.F.);

Franziska.wolf@haw-hamburg.de (F.W.)

2 Department of Natural Sciences, Manchester Metropolitan University, Manchester M1 5GD, UK

3 College of Architecture and Planning, Imam Abdulrahman Bin Faisal University, Dammam 31441, Saudi Arabia

4 Department of Geography and Environmental Sciences, Faculty of Engineering and Environment, Northumbria University, Newcastle upon Tyne NE1 8ST, UK; richard.kotter@northumbria.ac.uk

5 Department of People and Technology, Roskilde University, 4000 Roskilde, Denmark; tskoug@ruc.dk

6 Geospatial Analysis and Modelling Research Group, Department of Civil and Environmental Engineering, Universiti Teknologi PETRONAS, Seri Iskandar 32610, Malaysia; alateef.babatunde@utp.edu.my

7 Graduate Program in Civil and Environmental Engineering, University of Passo Fundo, São José 99052-900, Brazil; amandasalvia@gmail.com

check for updates

Citation: Leal Filho, W.; Abubakar I.R.; Kotter, R.; Grindsted, T.S.; Balogun, A.-L.; Salvia, A.L.; Aina, Y.A.; Wolf, F. Framing Electric Mobility for Urban Sustainability in a Circular Economy Context: An Overview of the Literature. Sustainability 2021, 13, 7786. https://doi.org/10.3390/su13147786

Academic Editor: Thanikanti Sudhakar Babu

Received: 29 May 2021

Accepted: 6 July 2021

Published: 12 July 2021

Publisher's Note: MDPI stays neutral with regard to jurisdictional claims in published maps and institutional affiliations.

Copyright: (c) 2021 by the authors. Licensee MDPI, Basel, Switzerland. This article is an open access article distributed under the terms and conditions of the Creative Commons Attribution (CC BY) license (https:/ / creativecommons.org/licenses/by/ $4.0 /)$.
8 Department of Geomatics Engineering Technology, Yanbu Industrial College, Yanbu 41912, Saudi Arabia; ainay@rcyci.edu.sa

* Correspondence: irabubakar@iau.edu.sa

\begin{abstract}
The development of electro-mobility is one of the centerpieces of European country attempts to reduce carbon emissions and increase the quality of life in cities. The goals of reducing emissions from the transport sector and phasing out fossil-fueled vehicles in (urban) transport by 2050 present unrivaled opportunities to foster electro-mobility. This paper provides a comprehensive review of the literature and provides a detailed analysis of the current development of electro-mobility in Europe, assessing social, economic, and environmental aspects under a circular economy (CE) context. It also examines the existing challenges and suggests ways of addressing them towards improving the environmental performance of electro-mobility and the urban quality of life. The paper argues that a narrow technology-only agenda in electro-mobility will be less successful without the imperative of the $\mathrm{CE}$, including not just materials and resources but also energy, to unlock the medium-term co-benefits of de-carbonization of both the transport as well as the building and energy sectors. The paper critically reviews some of the anticipated future developments that may guide the growth of this rapidly growing field into a CE.
\end{abstract}

Keywords: circular economy; electric mobility; Europe; carbon emission; transport; urban sustainability

\section{Introduction: Electric Vehicles and Electro-Mobility}

Modern electric vehicles (EVs) are increasingly deployed around the world for electromobility, with ambitious targets set by the mature industrialized and currently industrializing countries. Electro-mobility (e-mobility), which refers to vehicles that can be fueled by the electricity network with or without an auxiliary internal combustion engine, is part of the landscape of (ultra-) low emissions vehicle-based transport, mostly in urban environments. As electricity is an energy vector, rather than the principal energy source, it is critical to explore both the degree (of electrification) and the volume (consumption) of electricity used to power transportation and the supporting infrastructure along the supply chain. It is equally significant to examine the source of electricity generation (i.e., to what extent it is from renewable sources, and with what equivalents of $\mathrm{CO}_{2}$ emissions). 
In the current global trend of increasing populations and personal vehicles in cities, the use of an e-mobility strategy can represent a partial solution to many sustainability challenges including climate change, poor air quality, noise pollution, and energy security if connected to renewable energy (RE) as well as closer/closed resource loop cycles, and if developed at scale with an efficiency increase also in terms of fuel cost [1-4]. There are also substantial numbers of non-city EV users commuting into cities for work, self-sufficiency, and environmental concerns [5]. E-mobility can be key in reducing fossil fuel consumption, provided the source of electricity generation is shifted away from those sources, and its transmission and distribution are decarbonized and designed with the lowest losses possible. According to a recent global overview of EVs [6], cleaner energy generation, better recycling schemes, and further improvements to electric vehicle battery technology are needed before electric cars, vans, buses, and trucks can contribute their full environmental and economic potentials. E-mobility is vital to the European sustainable mobility agenda. By 2050, fossil-fueled vehicles are likely to be proscribed in cities and replaced by other technological alternatives such as battery electric vehicles (BEVs) [7]. The Circular Economy (CE), as well as e-mobility if designed and executed in a deep sustainability way, is relevant to contributing towards the United Nations (UN)'s Sustainable Development Goal (SDG) 12 (Responsible Consumption and Production), SDG 13 (Climate Action), SDG 9 (Industry, Innovation, and Infrastructure), SDG 11 (Sustainable Cities and Communities)—relying on the action in the domain of SDG 7 (Affordable and Clean Energy). The 17 SDGs are the replacement of the UN's Millennium Development Goals at the international/global level and are also connected to a trajectory from the UN's Conference on Environment and Development (UNCED) in 1992 (also known as the Rio Summit), with its associated (in the Annex) Local Agenda 21. There is now also the Local 2030 Agenda of the UN, which brings together leaders from national, regional, and local governments, the $\mathrm{UN}$, the private sector, civil society, philanthropy, and academia to collaboratively develop and implement solutions that will advance the SDGs at the local level.

\subsection{The Circular Economy and E-Mobility: Recent Trends}

Recently, arguments around connecting CE with the e-mobility industry have been developed further. For instance, in the autumn of 2020, the German Circular Economy Initiative Deutschland (CEID) [8] used the example of electric car batteries to illustrate what can be achieved by a closed-looped system around the integration of traction batteries by 2030. The CEID formulated proposals and recommendations for government, science, and industry for building a system of products and services that maximize value creation throughout a traction battery's entire life cycle. This included suggested actions around more transparent information on traction battery life by setting incentives and establishing IT systems to improve the provision of battery data both during and after the end of life, for example through battery passports (backed also by Avere, the European Association of Electromobility). Furthermore, a European battery disassembly network is suggested in terms of the physical infrastructure to support reverse logistics and the dismantling of vehicle traction batteries [8-11]. This is important, as there is a clear trend of a substantially increased establishment of traction battery production for e-mobility in Europe.

Likewise, the overall agenda of the European Raw Materials Alliance (ERMA) announced in September 2020 as part of an EU Action Plan on Critical Raw Materials "to reduce Europe's dependency on third countries, diversifying supply from both primary and secondary sources and improving resource efficiency and circularity while promoting responsible sourcing worldwide" [12]. Similarly, the publication of the 2020 List of Critical Raw Materials by the EU proclaims its intention to contribute to "the best framework for raw materials and the CE worldwide". By 2030, the activities of ERMA are meant to "intensify the production of raw and advanced materials and to address CE by increasing the recovery and recycling of 'Critical Raw Materials.' The activities include: (a) intensifying the development of "environmentally and socially equitable innovations and infrastructure" (b) implementing a CE of complex products such as EVs, clear (and clean) tech, and 
hydrogen equipment, (c) supporting the capability of Europe's raw materials industry for extracting, designing, manufacturing, and recycling materials, and (d) promoting innovation, strategic investment, and industrial production across specific value chains" (p. 1).

Wurster et al. [13] state that developing sustainable CE ecosystems requires the partaking companies (organizations) to engage customers in innovation processes. They note that so far "specific preferences of the end-users of sustainability-focused cars such as EVs and users of biofuels are unknown in the CE context" (p. 1). They see open innovation ecosystems as the way forward for the $\mathrm{CE}$ and define it as the emerging sets of actors, activities, institutions, and relations that are essential for innovation in a CE (p. 2). One automotive systems component for EVs that has recently been investigated from the sustainability and sourcing through the value chain angle is tires, with some manufacturers now producing EV-specific ones, due to the often relatively higher weight of EVs compared to the equivalent Internal Combustion Engine (ICE). Given the current oversupply of End-of-Life tires (from ICEs in volume), the potential of CE tires and bio-based tires has been conceptually explored in the context of an acceptance model and labeling/marketing based on that [14].

\subsection{Renewable Energy Sources as Part of Electric Mobility and the Circular Economy}

EVs can increasingly use RE sources, thereby reducing the carbon footprint from a life cycle assessment viewpoint, which tallies with the EU's 2008 Strategic Energy Technology Plan to ensure its leadership in developing and deploying cost-effective low-carbon energy technologies. Using RE sources in the electricity production mix is important since the well-to-wheel cycle consists of the entire production chain and vehicle operation: well-totank (WTT) and tank-to-wheel (TTW) emissions. For instance, the Union of Concerned Scientists notes considerable differences across the United States regions/metropolitan areas in electricity generation sources, leading to markedly different outcomes for the environmental profiles of EVs [15]. Thus, communication attempts are needed to frame the relative advantages of EVs, smart charging, and bi-directional charging to a wide range of stakeholders, and the net carbon savings between comparable ICE vehicles and EVs powered through a plugin, battery swapping, or inductive/wireless charging. This could be as a smart meter or like the MyGridGB smart home's Dashboard (displaying live electricity data for Great Britain by generation source of low-carbon electricity and carbon intensity by generation type, and trends in electricity demand and supply) [16]. Hoekstra [17] (p. 1412) maintains through comparative BEV and ICE sample calculations (including a speculative 'renewable (energy) scenario') that the "greenhouse gas (GHG) emission reductions possible with battery electric vehicles (BEVs) are underestimated in the scientific literature. The following causes are identified and illustrated: overestimating battery manufacturing, underestimating battery lifetime, assuming an unchanged electricity mix over the lifetime of the BEV, using unrealistic tests for energy use, excluding fuel production emissions, and lack of system thinking."

\subsection{Towards Contributions to the United Nations Sustainable Development Goals}

The importance of e-mobility is emphasized in the Sustainable Development Goals (SDGs), a set of 17 global goals agreed by the UN in 2015, such as in SDG 7 (encouraging the use of clean energy), SDG 11 (helping cities to use energy sustainably and integrate public charging options to facilitate e-mobility), and SDG 13 (reducing carbon emissions) [18,19]. The transport sector accounts for about one-quarter of the total GHG emissions and is among the sectors contributing the most to climate change [20]. To limit global warming to $1.5^{\circ} \mathrm{C}$ above pre-industrial levels, investments in e-mobility are crucial as over one billion passenger cars are on roads worldwide today, which could double by 2040 [21]. Likewise, the CE has significant important connections with several SDGs (Table 1) [22]. 
Table 1. Comparing the principles of e-mobility sustainability and the CE. Source: adapted from German Federal Environmental Agency, 2020. The table is adapted, on the left, from the German Federal Environmental Agency (2020), 9 Principles for a Circular Economy, Dessau, Germany (p.8) [23] https://www.umweltbundesamt.de/sites/default/files/medien/1410 /publikationen/2020_10_23_leitlinie_kreislaufwirtschaft_englisch_bf.pdf (accessed on 15 May 2021). The right side is newly created by the authors.

Principles of E-Mobility Sustainability
Work in progress in electric mobility on
resource-efficiency of using components and
energy use, but with many advantages over
Internal Combustion Engines in greater simplicity
of traction systems (battery electric vehicles).
Minimize loss of electricity/energy in
distribution systems also.

No tail-pipe emissions of battery electric vehicles, in terms of greenhouse gases and urban air pollutants.Improvements in well-to-wheel emissions are still being enacted and depend on inputs and scenarios in the extraction of primary resources and production sources of electricity (as well as its distribution).

Objectives Second-life and recycling of components (including electric traction batteries) still under development, as well as of used vehicles.

Holistic business cases for electric mobility are still being developed and discussed. Currently, most are operating with some level of public subsidy.

Financing The internalization of public health (air pollution avoidance) and the ecological cost is critical here, and also smart grids/digitalization co-benefits.

Second-life/re-use, cradle-to-cradle design, and

Reusage recycling are still being much discussed in electric mobility and being worked on by a range of actors.

Second-life/re-use, cradle-to-cradle design, and recycling are still being much discussed in electric mobility and being worked on by a range of actors.

Reduction

The lifespan of electric mobility components

(including electric traction batteries) can be extended/maximized with smart and responsible strategies.

\section{Principles of Circular Economy}

Definition: "The circular economy is part of a resource-efficient, sustainable way of life and management, encouraging the implementation of the UN's Agenda 2030 for Sustainable Development, and respecting planetary boundaries." (p.8).

Scope: "The concept of a circular economy encompasses not only traditional waste management but all phases of material and product life cycles. It must be viewed from a global perspective, including cross-border flows of raw material, goods and waste, and their associated environmental and social effects as well as long-term aspects such as stocks of goods and resulting material flows." (p. 8)

Objectives: "The circular economy helps to protect natural resources and the climate, as well as the environment and human health, following the precautionary principle. In addition, it aims at securing raw material supplies. The circular economy is meant to reduce negative impacts

along the life cycle of materials and products-by economizing on primary materials and substituting them with secondary materials-and of waste generation and waste management." (p. 8).

Measuring expenditure: “The expenditure for circular economy measures should be compared to the expenditure of the primary raw materials industry with associated environmental impact, including external social and environmental costs, for producing the same materials or materials or goods fulfilling the same function." (p.8)

Material cycles: "The circular economy aims at managing materials in same or higher value cycles so that primary materials can be replaced by secondary material of suitable quality, thus economizing on primary material. However, cascading use and final disposal of materials are also required to achieve the objectives and expenditure criteria." (p. 8)

Prevention: “Designing products for a circular economy means retaining the functional and economic value of products, their components, and materials as long as possible to minimize negative impacts on humans and the environment. Design concepts should sustain the reorganization of ways of production and consumption within society. Optimum design must be evaluated in terms of achieving the objective and expenditures required." (p. 8). 
Table 1. Cont.

\begin{tabular}{|c|c|c|}
\hline & Principles of E-Mobility Sustainability & Principles of Circular Economy \\
\hline Smart Design & $\begin{array}{c}\text { Work is ongoing on components of electric traction } \\
\text { batteries and recycling, as well as safety and } \\
\text { toxicity issues, by a range of actors }\end{array}$ & $\begin{array}{l}\text { Design: "Designing products for a circular economy } \\
\text { means retaining the functional and economic value of } \\
\text { products, their components and materials as long as } \\
\text { possible in order to minimise negative impacts on humans } \\
\text { and the environment. Design concepts should sustain the } \\
\text { reorganisation of ways of production and consumption } \\
\text { within society. Optimum design must be evaluated in } \\
\text { terms of achieving the objective (3) and expenditures (4) } \\
\text { required." (p. 8). }\end{array}$ \\
\hline $\begin{array}{l}\text { Pollution } \\
\text { potential }\end{array}$ & $\begin{array}{l}\text { Electric mobility-especially if battery mode } \\
\text { only-removes urban air pollutants (including } \\
\text { particular matters). Reuse and recycling of } \\
\text { components (including electric traction batteries) } \\
\text { are being worked on by a range of actors. The } \\
\text { source of electricity production (renewable, rather } \\
\text { than fossil fuel-based) matters also.The authors are } \\
\text { neutral for the present purposes of nuclear energy } \\
\text { (as are most official sources). }\end{array}$ & $\begin{array}{l}\text { Pollutants: "It must be avoided to place products on the } \\
\text { market that contain substances that have an adverse effect } \\
\text { on the public interest and, in particular, on human health } \\
\text { and the environment. If such substances cannot be } \\
\text { substituted, are already contained in products, or are only } \\
\text { later identified as harmful, the substances must be } \\
\text { destroyed or stored safely in final sinks. Alternatively, } \\
\text { after weighing up the objectives and expenditure, they can } \\
\text { also be transferred into safe cycles that prevent the } \\
\text { accumulation of harmful substances." (p. 8). }\end{array}$ \\
\hline CSR & $\begin{array}{l}\text { There are still major issues currently being worked } \\
\text { on by a range of actors, for original equipment } \\
\text { manufacturers and their corporate social and } \\
\text { environmental responsibilities concerning critical } \\
\text { key components, such as "rare metals" for electric } \\
\text { traction batteries and other conductive } \\
\text { components in electric mobility infrastructures. }\end{array}$ & $\begin{array}{l}\text { Responsibility: "In a circular economy, all players within } \\
\text { product life cycles and along material value chains bear } \\
\text { responsibility for achieving the objectives of the circular } \\
\text { economy. Where responsibility is not assumed otherwise, } \\
\text { legal requirements must be implemented." (p.8). }\end{array}$ \\
\hline
\end{tabular}

This article provides a comprehensive analysis of the current development of electromobility in Europe, assessing social, economic, and environmental aspects under both a CE context and a sustainable urban mobility planning perspective. It also examines the existing challenges and suggests ways of addressing them towards improving the environmental performance of electro-mobility and, inter alia, urban quality of life led by reduced $\mathrm{CO}_{2}$ emissions and noise.

\section{Methods}

This paper uses a two-method approach. Firstly, it comprehensively describes trends in e-mobility within a sustainability and CE perspective. Secondly, it provides an in-depth literature review, and the use of secondary data is drawn upon. The paper also draws on project work/reports for two recent successfully concluded EU Interreg projects (Baltic Sea Region (BSR) Electric and Smart, clean Energy and Electric Vehicles for the City (SEEV4City)), both of which produced state-of-the-art review reports of literature and policy, as well as deliverables based on pilot/innovation/use cases within those projects across multiple European countries [24,25]. The literature review queried multiple academic and industry databases (Web of Science, ScienceDirect, Google Scholar, and electrive.com). Key search terms used included "e-mobility", "electro-mobility", "low-emission vehicle-based transport", "Europe", "electric vehicle", "zero-emission vehicle", "circular economy", and "electro-mobility services". Retrieved articles and reports were selected based on relevance to the topic and currency. The contents were arranged in themes, analyzed, and synthesized as done in previous studies [26]. The outcome was used in gaining further insights into the topic and developing subtopics to be investigated (Table 2). 
Table 2. Themes developed for the study through a state-of-the-art literature review.

\begin{tabular}{|c|c|c|c|}
\hline Themes & Data Source & Interpretation & Insights \\
\hline $\begin{array}{l}\text { Overview of e-mobility } \\
\text { in Europe and forms of } \\
\text { e-mobility }\end{array}$ & $\begin{array}{c}\text { Books, journal } \\
\text { articles, reports, } \\
\text { organizational websites }\end{array}$ & $\begin{array}{l}\text { Illustrative and } \\
\text { descriptive }\end{array}$ & $\begin{array}{l}\text { Reducing carbon and noise emission due to } \\
\text { e-mobility. Decarbonization through RE is also } \\
\text { required. E-bikes, e-buses, and e-scooters will } \\
\text { play roles in achieving e-mobility in urban areas }\end{array}$ \\
\hline Fostering sustainability & $\begin{array}{l}\text { Books, journal articles, } \\
\text { reports }\end{array}$ & $\begin{array}{l}\text { Illustrative and } \\
\text { descriptive }\end{array}$ & $\begin{array}{l}\text { Reduction of air pollution but energy } \\
\text { consumption might increase; the possibility of } \\
\text { new job creation }\end{array}$ \\
\hline Context of CE & $\begin{array}{l}\text { Books, journal articles, } \\
\text { reports, organizational } \\
\text { websites, regulators }\end{array}$ & $\begin{array}{l}\text { Illustrative and } \\
\text { conceptual }\end{array}$ & $\begin{array}{l}\text { Principles of a CE-preservation of materials, } \\
\text { elongation of life cycles, reduction of distances }\end{array}$ \\
\hline $\begin{array}{l}\text { Perspective/principles } \\
\text { of sustainable urban } \\
\text { mobility planning }\end{array}$ & $\begin{array}{l}\text { Books, journal articles, } \\
\text { reports, organizational } \\
\text { websites, news articles }\end{array}$ & $\begin{array}{l}\text { Illustrative and } \\
\text { conceptual }\end{array}$ & $\begin{array}{l}\text { Electro-mobility is an important-but by no } \\
\text { means the only-perspective to take on board, } \\
\text { alongside other (and to be prioritized, where } \\
\text { possible) modes of transport (active travel); } \\
\text { inter-modal transport is important, as is spatial } \\
\text { planning and social and organizational } \\
\text { engagement/participation and collaboration }\end{array}$ \\
\hline $\begin{array}{l}\text { Fostering e-mobility } \\
\text { solutions }\end{array}$ & $\begin{array}{l}\text { Books, journal articles, } \\
\text { reports, websites }\end{array}$ & $\begin{array}{l}\text { Explanatory and } \\
\text { analytical }\end{array}$ & $\begin{array}{l}\text { Different e-mobility solutions, with } \\
\text { trends analysis }\end{array}$ \\
\hline
\end{tabular}

The methods used in the BSR Electric and SEEV4-City EU Interreg projects are also drawn on here in terms of key deliverables (outputs) comprised of systematic state-ofthe-art literature reviews, stakeholder mappings, policy expert and industry surveys, collaborative workshops and webinars, in-depth interviews with sampled key actors, and utilizing public statistical data on e-mobility, legislation and public policies, analysts' and professional/industry journalism accounts of organizational behaviors, strategies, and activities, and content and discourse analysis of statements by those organizations/industry players that are publicly available on their websites.

\section{Results from the Analysis and Literature Review}

\subsection{Forms of E-Mobility_A More Holistic Lens for Sustainable (Urban) Transportation}

Cities, including their rural hinterlands, have holistic targets for decarbonization, with the decarbonization of transport as one of the major targets. Depending on the nature of the city, this may only be road surface-related, though in most it is also related to light rail in different shapes. In most cities, this is also related to urban and warehouse logistics. For some cities, it prominently includes inland waterways or is inland or maritime portsrelated. For all these dimensions, both the types of vehicles (or vessels) as well as their energy / power source are important for decarbonization. Low emission vehicles, including electric cars and vans, e-buses [27,28], e-bicycles and pedelecs [29-32], e-scooters [33], electric motorbikes, electric trams, e-ferries, and e-logistics (such as forklifts) $[34,35]$ are increasingly being implemented as sustainable transport and climate strategies.

For the most part, the focus is-due to quantity and collective impact-still heavily on electric cars (and vans), as well as public transport. However, private e-cars especially are not the full answer to mobility and environmental problems when they only partially replace ICE vehicles by serving as the second household vehicle, thus not reducing traffic congestion [36]. The notion of "zero-emissions vehicles" is largely a marketing framing, since it only applies to full BEVs, not Hybrid Electric Vehicles (HEVs) [37].

To further address the field of commercial city logistics, the BSR Electric project (Figure 1) collaboratively developed a set of hands-on checklists for a range of actors, i.e., a tool to facilitate decision-making and corresponding investments in a range of e-mobility solutions, e.g., to support the uptake of electric vans and e-logistics [33,38]. E-buses have seen a major upswing in cities in recent years (as well as other ultra-low carbon technologies 
for fueling buses, such as hydrogen). This is reflected in the BSR Electric use case on e-buses in Hamburg (Germany) and Tartu (Estonia). The BSR Electric project developed a checklist particularly for municipalities and public transport providers who want to accelerate the sustainable transformation of their bus fleet. Even though the checklists do not explicitly refer to the concept of $\mathrm{CE}$, its key dimensions, or recommended topics to consider for decision-making, they support the circular approach (see Figure 1).

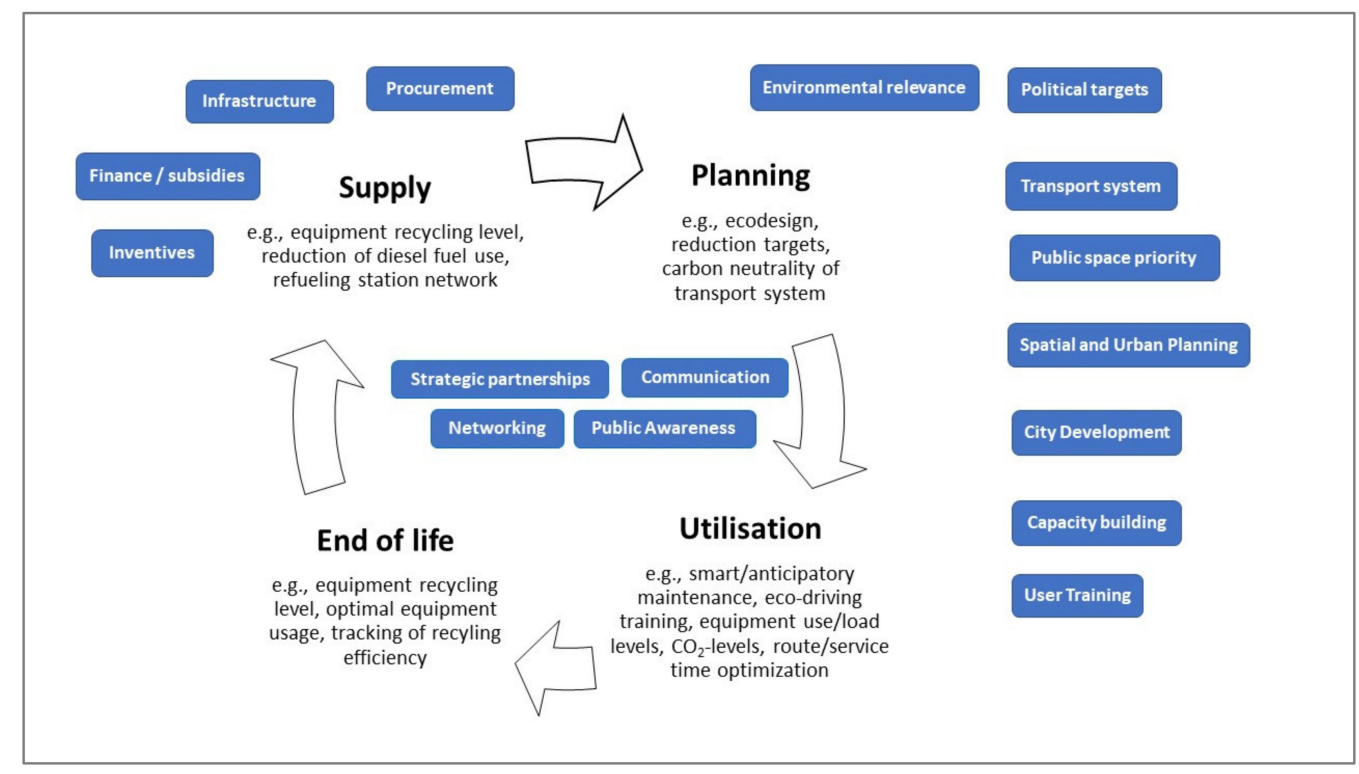

Figure 1. Value of action checklists for facilitating the transformation of transport systems. Note: The blue boxes indicate recommended topics that the BSR electric project identified and highlighted in their distinctive action checklists; only the 'End of Life' phase of recycling was not explicitly addressed in the various project use cases (e-vans, e-buses, e-bikes, e-scooters, e-ferries). Source: Authors.

E-bikes are also increasingly becoming a part of mobility concepts in several cities, because e-bikes can be used for longer routes into and within the city and are gradually replacing car use due to their positive health and environmental impacts [28-36]. This approach ties in with the principles of the Sustainable Urban Mobility Planning (SUMP) agenda of prioritizing active travel and reducing or substituting (on a socialneeds basis) private motorized transport in particular, but e-cargo bikes have also been used to replace (especially for the last mile) motorized commercial road logistics [39]. Public transport and shared transport are also favored by the SUMP agenda over private transport, with an electrification agenda of those since the 2019 update of the guidelines for the development and implementation of the Sustainable Urban Mobility Plan with some associated (updated and new) topic guides and practitioner briefings [40]. However, what is missing so far in all the now-available SUMP guidance is an explicit and detailed focus on RE source charging infrastructure to underpin this electrification agenda [25]. Likewise, no explicit focus on CE principles appears evident either. Overall, SUMP strategies or similar approaches diagnose that a range of publicly organized mobility services is needed in cities for a more sustainable mobility landscape that is both environmentally and socially delivering for work, leisure, economy, and social lives [41]. Shared e-mobility (car-sharing and car clubs) is slowly expanding with potential under a range of socioeconomic and behavioral conditions, alongside Information and Communication Technology (ICT) and optimized system deployment issues [42].

E-scooters, e-tricycles, and e-motorcycles are mostly lightweight and thus energyefficient, and their batteries can be small without losing too much range and allow for replacement and cost-efficient charging equipment including smart recharging stations [43]. According to Apostolou et al. [44], the leading target group of Dutch solar e-bikes is that of commuters in the 40-60-year-old age group, with commuting distances longer 
than $6 \mathrm{~km}$ and a gross income higher than $€ 2500$. They conclude solar-powered e-bikes that can serve as a sustainable way of urban transport by displacing some conventional transportation. For e-bikes (bicycles, both for commuters and families), the BSR Electric project collaboratively produced an action checklist for a range of implementing local level actors [45]. However, users of e-scooters are confronted with having to check which roads they are allowed on, because they are too fast for general bicycle lanes but a traffic hazard when combined with cars. Most e-scooters do not have a clearly defined legal status [33].

\subsection{Electric Transport Vehicles}

In Norway, the fully electric car ferry Ampere began operating in 2015 [46]. E-boats have far lower costs for fuel than conventional diesel ferries, thereby having a crucial impact in reducing carbon emissions [34]. Two ferries connecting Sweden and Denmark (Helsingborg to Helsingör) made the switch-over to fully electric in 2017 [47]. A similar switch-over at a much smaller scale was implemented in the French holiday town of Capbreton in 2019 with a fully recyclable aluminum hull [48]. The BSR Electric project recently collaboratively produced an action checklist for e-ferries, from which other watercourserich cities (such as Oslo and Amsterdam, which are moving towards electrification of their ferries) can benefit as well [49].

Market interventions for a transitional duration to reduce acquisition and operational costs of EVs versus ICEs must be accompanied by efforts to overcome the challenges e-mobility faces, such as technical and infrastructural limitations, consumer awareness, and ecological and economic cost-benefit issues that depend on the content and perspective taken [50-53]. Other challenges are the interplay between the automotive and the ICT/mobility services industry, fast charging systems, availability of electricity, building, and RE infrastructures, insecurity of consumers and their (un)willingness for behavioral change and adaptation, regulatory and emerging taxation, local trading of decentralized energy, and battery capacity, degradation, life-cycle, and environmental burdens-unless significantly relieved by second-life applications and the recapture of key elements in the EV batteries.

Social conditions - such as the transfer of knowledge and raising awareness of the advantages and process of EVs, with preferential treatments and incentives-are very important for fostering e-mobility solutions in urban areas. Changing social norms and organizational behavior (around fleets and with business-provided vehicles) and framings of mobility styles and entitlements should be encouraged and regulated by a reinforcing relationship between transportation, land use, and energy planning, in the context of digitalized, energy-efficient, connected, and socially livable cities [54,55].

Nykvist and Nillson [56] (2015) reported that Stockholm was not leading in BEV uptake innovation at the time because of a lack of niches, which limited the experiences of BEVs within a regime favoring plug-in HEVs and with cognitive and normative barriers. Limited support for BEV was associated with anxiety about selecting technology winners and repeating past policy mistakes. Van der Hoed et al. [57] derive lessons learned from integrating electric mobility, RE, and Smart Charging and Vehicle to Everything (V2X) technologies, concluding that the V2X setups need to be tailor-made by coalescing prevailing but not yet readily compatible components, that it pays to know the V2X market, and that there is no universal V2X business model. Kester et al. [58] compare the logic and arguments behind EV incentives and policy mechanisms among Nordic cities. Perceived as the highest incentives were the cost reduction mechanisms (especially tax exemptions), infrastructural support for public and residential charging, consumer awareness, procurement programs, and environmental zones. The merits and demerits of these mechanisms vary by nation, transport segment, the transition phase, and market share. The study advocates "strong stable national targets and price incentives combined with local flexibility to implement secondary benefits and give more attention to awareness campaigns to advance the implementation of electric vehicles." Kotilainen et al. [59] (2019) focused on the Nordic countries with common decarbonization targets for the (road) transportation sector, 
interwoven electric energy systems, and a joint electricity market largely based on low carbon energy generation. They detected technological, institutional, and behavioral mechanisms that can either constrain or enable a transition by shaping national socio-technical systems and regimes. Incumbent industries can shape policy choices through the lock-in into institutional inter-dependencies. A buildup of social and material features and the vested interests of actors could result in regime-level inertia, but technological lock-in can benefit EVs through learning effects from technologically interrelated wind energy projects as well as available infrastructure in buildings that support EV charging. Kester et al. [60] draw on a range of interviews with electric mobility experts in the Nordic region to suggest that Vehicle-to-Grid (V2G) is still unfamiliar among private transport, electricity, and EV experts. Identified obstacles include flexible storage markets and the role of aggregators charging infrastructure sites and electricity distribution companies. Recommendations consist of new/revised regulations, taxes, pilot projects, planning, and communication.

Thus, (renewable energy-charged) EVs provide an environmentally friendly urban mobility alternative, but currently, a large-scale uptake is still undermined by comparatively high acquisition costs and charging infrastructure (e.g., actual costs for EV charging depending on access to it). In Sweden, for instance, the vehicle cost, range, and infrastructure development hinder consumer acceptance of EVs [61]. Delays in EV delivery and the limited driving range of most EVs (about 100-150 miles) can cause higher relative costs on longer trips (p. 116). Charging infrastructure is still limited. The Netherlands and Denmark have about 1 charger per 4-8 EVs, with Norway's ratio at 1 charger per 20 electric cars-far below the global average of 1 charger per 10 electric cars [61] (p. 40). Danish government politicians are currently revisioning the planning law to implement zero-carbon zones so that every local plan in cities either requires or needs to consider charging infrastructure in future planning proposals. Transport \& Environment's (T\&E's) (2020) report and recommendations on the required EV charging infrastructure during the current decade until 2030 across the EU note that "instead of simply counting each charge point as one, T\&E's supply metric proposes to weigh charge points based on how much energy they can provide to the electric vehicle fleet and how available they are to the public. This metric should be used to set the EU public charging infrastructure deployment targets for each country for 2025 and 2030, corresponding to 1.3 million public charge points EU-wide in 2025 and close to 3 million in 2030" [62] (p. 3). It also states that smart charging systems are capable of aligning charging events with electricity generation, due to charge session monitoring and control structures that adjust to flexible electricity pricing. Public charging systems should at the minimum have an "intelligent metering system" (p. 4). Taxis are a significant segment targeted for electrification (and in some cities, such as Amsterdam, to be fully electric) with their specific demands due to long durations of service and short turn-around [63]. Slow charging stations are most common in European cities, but the amount of fast charging stations is rising. Local demand for electricity due to large numbers of EVs fast charging will place a substantial burden on the national power grid, needing substantial increases in RE generation to avoid environmental impact. Addressing these challenges requires reframing e-mobility both under deeper sustainability as well as under a CE context.

The policy proposals put forward by the SEEV4-CITY EU Interreg project, with project partners Polis and Avere as the key professional and industry network/platform organization alongside the academic researchers, have developed such a set of suggested ways of progressing this [64], with suggestions also for a wider European (EU and UK) roadmap currently being further devised (Table 3) [25]. Van Bergen et al. observe a range of types of pilot energy services and suggest the upscaling of types of use cases [65]. These were based also on the learnings derived from understanding and further developing (including for the future) business models for several larger and smaller operational pilots of different complexity and kinds of vehicle-for-energy services (depending on the preferred strategies and interest of the participating local actors' vehicle-to-building or 
vehicle-to-grid and different settings of smart charging to Vehicle-to-Grid characteristics at present, or for the near future) (Figure 2).

Table 3. Selected SEEV4-City recommendations for policy-makers at EU/national levels (on the right) and local/regional levels (on the left) [25].

\section{SEEV4-City Project Policy-Recommendations}

Harmonize the existing energy and mobility activities and plans/planning, including SUMPs, Sustainable Energy and Climate Action Plans (SECAPs), and Sustainable Energy Action Plans (SEAPs).
Long-term, agile, and integrated strategic planning in full alignment with the local/regional roadmaps, and based on the interdisciplinary and inter-organizational/interagency cooperation among public and private actors, including charge point operators (CPOs) and distribution systems operators (DSOs)

Establish clear political commitment and an explicit regulatory framework through the European Green Deal, specifically through the Strategy for smart Sector Integration and the Strategy on Sustainable and Smart Mobility, to fully enable smart charging and Vehicle-Grid-Integration's potential for climate protection, and a transport- and energy transition.

Remove existing barriers (i.e., through the effective implementation of the Clean Energy Package) and allow for full market participation of flexible electric loads such as smart charging infrastructure and V2G solutions, as well as flexible tariff structures, across the EU/in the EU Member States, European Free Trade Association (EFTA), and the UK.

Use the revision of the EU's Alternative Fuels Infrastructure

Directive (AFID)to support the roll-out (where applicable) of smart-charging and V2G-ready technologies in public, semi-public, and private infrastructures.

Provide a roadmap over a long enough period to stakeholders so that they can prepare and adapt accordingly, including making the appropriate investments and having the certainty of financial returns. Integrated Energy Management Systems, smart charging, and V2X approaches should become an integral part of the plans, ensuring future-proof planning.

Foster the integration of the energy, mobility, and digital sectors, allowing for optimization of the energy system as a whole.

Enhance demand-side flexibility to smartly manage the energy system, which has large shares of renewables and EVs. This will reduce the overall costs, including those for grid upgrades (central and local).
Avoid working in silos. Instead, Local and Regional Authorities (LRAs) should consider setting up inter-departmental and cross-cutting task forces within the municipalities, ensuring both vertical and horizontal alignment and exchange. This approach should also allow a more harmonized approach to reduce the danger for the process to become exclusively politically or business-driven

Close cooperation between private and public stakeholders along the entire supply chain, namely: energy providers, charging solution providers, consumers, public authorities (mainly the above-mentioned cross-cutting task forces). This approach will help in reducing the danger for the process to become exclusively politically or business driven.

Develop strategies applicable to local circumstances instead of a "one size fits all" approach.

Promote smart charging and V2G solutions in the roll-out of the public charging infrastructures and include (whenever possible) concession granting and/or state aid as a requirement in the procurement.

Green incentives need to be accompanied by infrastructure, i.e., parking, shared charging stations, etc. It is important not only to

Develop a more integrated skill set for energy and transport intersection amongst planners, local authority managers, consultants, and technologists. consider affordability but also consumer convenience.

One of the critical fields to address is both focused and public communication. The BSR Electric project did so by developing theme-specific recommendations for municipalities, politicians, companies, and organizations. Based on the findings from piloting activities, the project partners established hands-on guidance for the target group in support of informed decision-making [25]. The BSR Electric project also developed an interactive and openly accessible online learning module for local/regional decision-makers in public and private entities as well as urban transport actors within the Baltic Sea Region and beyond, as well as for those who are currently studying this field and will be the decision-makers of the future. All findings were consolidated in an interactive Baltic Sea Region Roadmap for Urban E-Mobility, which summarizes the BSR Electric project's results across all work packages and is directed at general and theme-specific target groups, in particular urban transport planners, municipal and regional decision-makers, and civil servants, executives 
of city-owned companies and public transport providers in cities of the Baltic Sea Region, as well as researchers (Figure 3).

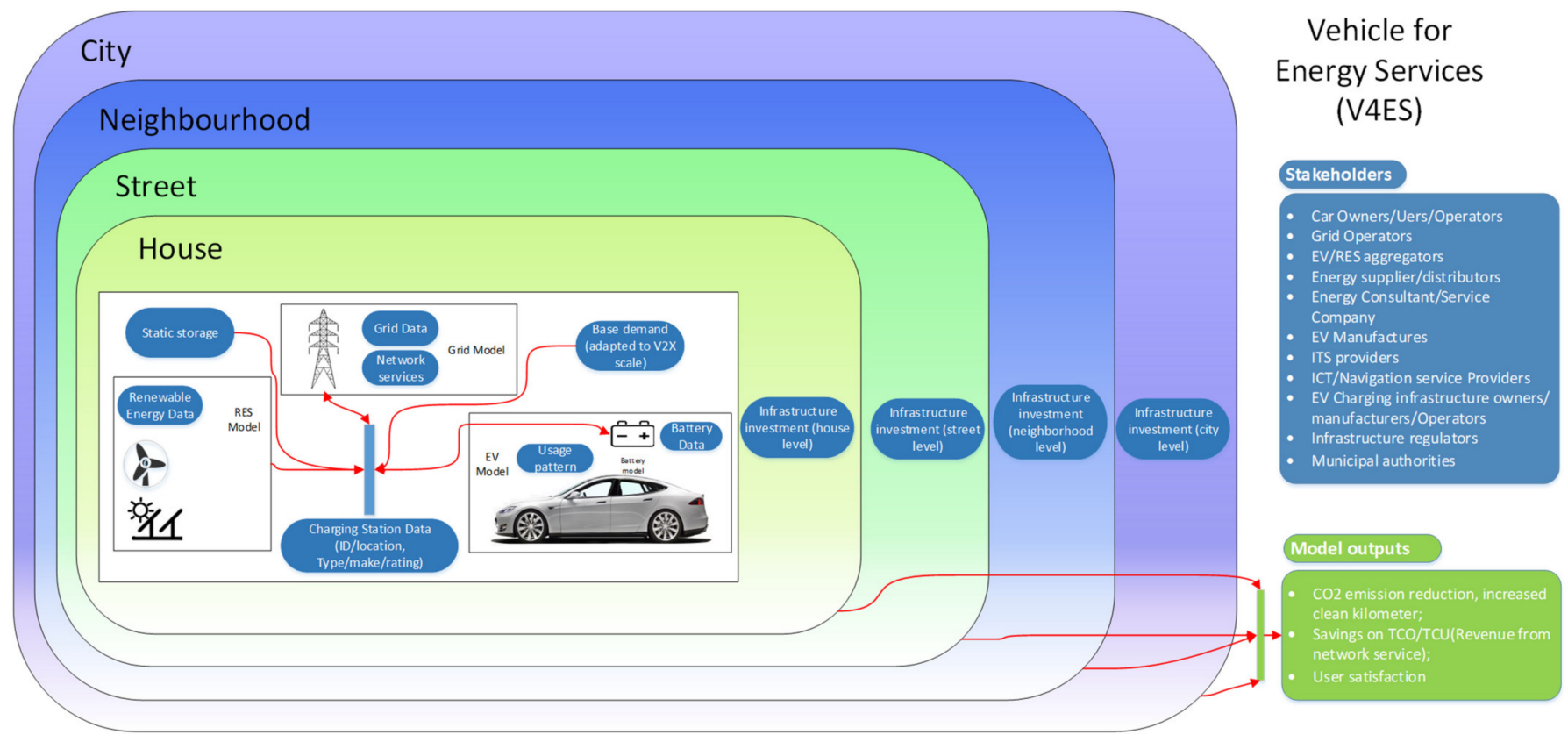

Figure 2. Electric vehicles for energy services. Source: Edward Bentley, Richard Kotter, Ghanim Putrus, Yue Wang, Ridoy Das, Geoff O’Brien (SEEV4-City EU North Sea Region Interreg project).

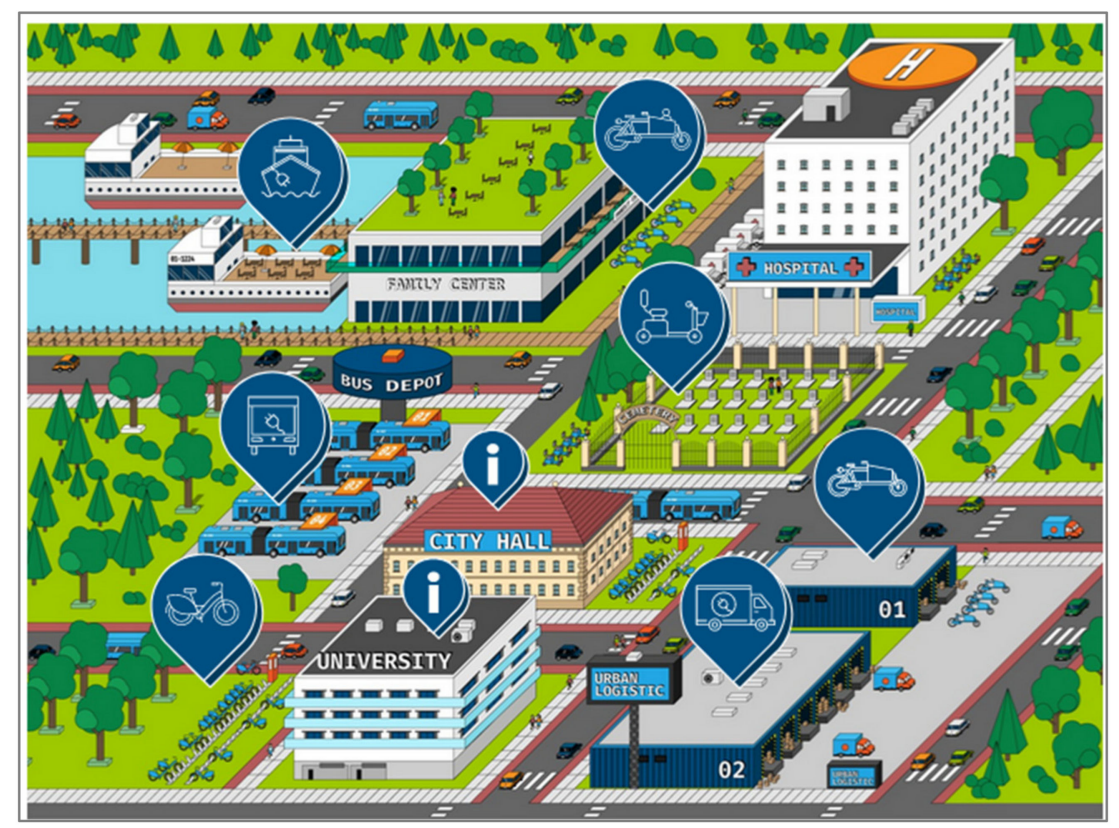

Figure 3. BSR electric roadmap offering interactive guidance on sustainable urban transport solutions. Source: https: / / www.bsr-electric.eu/results (accessed on 5 July 2021).

The Roadmap uses a nested 4-layer approach. The four different formats vary in their information depth and content and thus cater to the information needs of specific target groups, listed according to their information depth:

- $\quad$ Augmented reality static 3D model

- Folding map

- Website feature (interactive map, see image above) 
- Roadmap report: Single page view or double page view.

\section{Discussion}

\subsection{Socioeconomic and Environmental Aspects of Electro-Mobility}

The literature indicates that the transport sector grapples with increasing GHG emissions despite various interventions, which is largely due to dependence on fossil fuel for private and public transportation, with major environmental impacts such as pollution, noise, and climate change $[8,66,67]$. Shifting from ICE vehicles to e-mobility is necessary, as large-scale adoption of EVs can significantly reduce GHG emissions, bringing about more sustainable and healthier environments in cities by enhancing air quality, reducing dangerous emissions, and mitigating noise nuisance $[68,69]$. Successful reduction of emissions largely depends on the source and type of electricity utilized in EVs. As the substantial deployment of EVs results in increased electricity consumption, decarbonizing electricity generation must be advanced $[69,70]$.

E-mobility can also improve energy security by investing in energy generation [70]. Renewable energy is preferred to nuclear power to charge EVs in Germany and other countries; nuclear power mostly meets the electricity demand in many parts of France and Finland. However, in France, the share of RE sources (RES) in the electricity mix is increasing, particularly from solar and wind [71]. Distributed RES could present a problem for local electricity grids, as could a large rise in the uptake of (especially BEV) electric vehicles. Aligning those innovation trends could mitigate the impacts, producing co-benefits if charging periods of the EVs are matched with local RES production. Codani et al.'s [72] analysis of the implementation of this strategy by 2020 considers diverse local energy mixes across France as well as their seasonal dependencies. This reveals the "achievable green charging ratio" for the EV fleet per season and region, with and without a smart charging strategy. In Denmark and elsewhere, there is an increasing focus on using wind-generated electricity for e-mobility [73]. For some countries, future increases in RE generation might be inadequate to meet the increased demand by EVs, and stability snags are anticipated within electric grids because of high load spikes. Meeting increased energy demand poses severe challenges to electricity companies who may be forced to pursue RE solutions, including expanding existing ones. Smart charging and bi-directional charging could significantly ease these challenges according to several future energy system scenarios [74]. This can also include Plug-in Hybrid Electric Vehicles (PHEVs), although benefits from BEVs on average will be higher. There is also an expanding field of stationary energy storage (including second-life automotive batteries) that can perform grid balancing, peak shaving, and energy services for the grid, for instance in parking garages. Using EVs and direct coupling of several infrastructures (transport, logistics, ICT) also enhances the flexibility of electricity systems [75-77].

E-mobility supports market innovations in the automotive as well as ICT sectors, using new concepts and technologies. Energy providers and service companies are potential beneficiaries of the shift with new jobs created by increasing demand for onboard batteries, electric motors, and other related accessories [78,79]. However, market diffusion of EVs currently remains low, albeit with an upward trend in new registrations. Less than $2 \%$ of vehicles purchased in the EU in 2015 were electric, indicating a still-low popularity of EVs hinging on a general lack of understanding of its benefits $[71,80]$. The level of social acceptance enjoyed by fossil-driven conventional vehicles as well as continuous technological advancements in their design and operation (including fuel efficiency increases) are major reasons for their sustained dominance of the transport sector. Recent scandals on manipulated test results of most Original Equipment Manufacturers' (OEMs') diesel models have hit this segment, which was a peculiar European strategy by governments and regulators to comparatively reduce emissions, increase fuel efficiency, and reduce fuel costs not much adopted in the USA or Japan, with the latter's petrol-hybrid strategy (producing the Toyota Prius). Even before the diesel scandals in Europe and the US, GHG emissions reduction from a shift to diesel were (perhaps significantly) overestimated at just $1 / 10$ th, 
and "these minor savings are on the other hand overcompensated by a significant increase of supply chain $\mathrm{CO}_{2}$ emissions and extensive black carbon emissions of diesel cars without a particulate filter" [81]. They concluded that the European diesel car boom did not have the stated GHG emissions intervention objective and "toxic NOx emissions of diesel cars have been underestimated up to 20-fold in officially announced data."

The European transport sector is currently dominated by ICE vehicles with a total market share of 93\%, while a few years ago, the HEVs, plug-in hybrid, and BEVs only constituted about $1.8 \%$ and $1.1 \%$ of the market share, respectively [82]. EVs are usually expensive to purchase and are still comparatively limited in terms of a variety of available models compared to China's, Japan's, and California's toughening $\mathrm{CO}_{2}$ emissions cap for the average vehicle fleet of an automotive OEM. Although prospective buyers are not yet well informed regarding the capabilities of EVs, there are efforts to change this by stakeholders. Efforts to minimize GHG emissions via e-mobility have been largely successful with a $15 \%$ reduction in emissions, but this has not yet propelled substantial economic progress in the EV market.

\subsection{Accelerating Successful Transition to Electro-Mobility}

One way of improving the demand for EVs is through the implementation of supportive national incentive schemes and policies such as direct subsidies that have been proven effective [83]. Fuel cost savings offered by e-mobility and other favorable cash incentives are vital in promoting a shift to e-mobility. The Car Allowance Rebate System, offering significant payment to customers for replacing old vehicles with new environmentally friendly ones, was an economic stimulus instrument for the automotive industry following the global economic recessions after the 2008 financial crisis.

EV subsidies and rebate policies still vary internationally, according to European Alternative Fuels Observatory [84]. Wesseling [85] argued that the marked variance in national plug-in electric vehicle policies (comprising R\&D subsidies, infrastructure investments, and sales incentives) across 13 nations between 2008 to 2014 is explainable by exploring circumstances that could impact policy expenditures. Content and statistical analyses revealed that Plug-in Electric Vehicle (PEV) policies varied substantially among countries both in intensity and orientation, from a focus on supply-side innovation to demand-side environmental policy. The governments' role explained differences in PEV infrastructure investments but national PEV diffusion targets for 2020 surprisingly did not correlate with any national PEV policy. Economic interest in the automotive industry explained why large car-producing countries focused their policy on technology development and non-car producing nations on technology diffusion. Van der Steen et al. [86] noted the variance of EV policies pursued by different Northern European countries. In their view, these policies were not part of an evident policy strategy as they mainly addressed the introduction of e-mobility as an issue of "piling-up" enough incentives to overcome early market issues (e.g., high purchasing costs, mostly reticent or hesitant customers, a slow adaptation of regulation and standardization). They cautioned that in the short-term this may work - though also with the effect of a large share of HEVs in the market. Such a scenario is very prominent in the Netherlands, which may be either a transitioning step or springboard or more of a "valley of death" trap for full BEV-based electro-mobility. For the medium- and longer-term ambitions, these policies may not be viable. They called for alternative policy strategies reflecting "mixes" of policies stimulating a self-reinforcing loop in EV adoption.

The German experience shows that "electric cars will only be successful when part of a system innovation" [87], and this highlights the importance of involving society by making it aware of the new e-mobility options [88]. Spain acknowledges the private firms as vital for developing the e-mobility sector, and public authorities have worked on electrifying public and private transport in cities [89]. The Netherlands likewise has ambitious e-mobility targets, expecting to sell only "zero-emissions" cars by 2030, maintaining the increase in the number of EVs and the offer of financial incentives to remain among Europe's leaders 
in e-mobility [90]. Norway is another European country focusing on a high share of EVs in the transport sector [91]. In addition to financial initiatives, other strategies can be adopted to address the barriers preventing the full acceptance of e-mobility. These include further enhancement of existing charging infrastructures, extending the charging network to workplaces, railway stations, parking model shift change locations, retail locations, roadtax exemptions, and introducing flexible traffic rules such as the utilization of conventional bus lanes or free/reduced parking spaces originally designated for ICE vehicles [92]. Many councils have also charged no or low tariffs for roadside PEV recharging facilities. The construction, health, and other service sectors are also viable for e-mobility transition, considering the number of registered vehicles in these sectors and their relatively low mileage in daily commuting [83]. There are many such projects in European cities, with mostly small- to medium-sized fleets ranging from compact cars to vans.

Laurischkat et al. [52] identified business model patterns that improve the economic propositions of e-mobility. For instance, EV sharing (as part of distributed rental cars to pick up or car clubs) enables the co-creation of benefits between the users. This is increasingly adopted by co-housing schemes, public sector (social) housing and private sector schemes, and EV service providers, while the Vehicle-to-Grid model provides extra revenue for battery owners. Similarly, battery swapping has the potential to reduce lengthy charging times and prevent quick aging of batteries, even though the precise formulation of this by BetterPlace failed in Denmark and Israel. Battery swapping is getting a resurgence of interest in China. Whilst lifecycle costs of EVs are high, they offer opportunities for long-term cost savings when operational since electricity is cheaper than fuel for ICEs, in addition to reducing (GHG) emissions.

\subsection{Electro-Mobility under a Circular Economy Perspective}

Some industries are beginning to deploy e-mobility under a CE structure. For example, WRAP in the UK is collaborating with leading retailers, brands, re-use and recycling organizations, charities, and non-governmental organizations (NGOs) to address common e-mobility challenges and to deliver commercial, environmental, social, and resource benefits to the entire supply chain. The Electrical and Electronic Equipment Sustainability Action Plan 2025, for instance, is a "platform for developing a circular economy" [93]. Walcher and Leube [94] argue that design and product management are critical domains in the $\mathrm{CE}$ and should be pursued through the co-creation of all relevant key actors. A recent report by the Capgemini Research Institute [95] (p. 2) on sustainability issues for the automotive industry finds, inter alia, disjointed execution of sustainability initiatives and inconsistent focus on sustainability initiatives across the value chain. For instance, sustainable sales, marketing, aftersales, and mobility services and vehicle usage are pursued only by a minority. However, "sustainability is a strategic issue for the automotive industry with R\&D and sustainable manufacturing receiving greater attention." Furthermore, the Capgemini report contends that "two critical areas will drive maximum sustainability for the automotive industry: ensuring that electric vehicles are truly sustainable." Firstly, "based on the grid which charges EVs in the $27 \mathrm{EU}$ countries and the UK, for example, the shift to electric vehicles would cut the overall lifetime GHG emissions by about $37 \%$ for passenger vehicles while reducing the operating footprint by $75 \%$, when powered by renewable sources." Secondly, by "incorporating CE practices across the automotive value chain, CE can potentially offer big economic benefits and make EVs more sustainable. However, only $32 \%$ of the automotive organizations' supply currently contributes to the circular economy" [95] (p. 1).

In a systematic meta-review article on the management of (ICE) end-of-life vehicles (ELVs), Karagoz et al. [96] (p. 416) note that because of legislation and new regulations, actors like customers, producers, and treatment facilities are given new responsibilities in the ELV management process, and that "ELV management is of vital importance for environment conservation, circular economy and sustainable development." 
Konietztko et al. [97] (p. 1) argue that CE "maximizes the value of material resources and minimizes GHG emissions, resource use, waste, and pollution." For them, "circularity needs to be understood as a property of a system (e.g., the mobility system of a city), rather than a property of an individual product or service (e.g., a car or a car-sharing service). Hence, there is a need for more knowledge on how to innovate towards" circular ecosystems.

A company specializing in e-mobility and new digital services for energy-Enelmaintains that "particularly in the case of Enel X (a), sustainable mobility is an integral part of the CE paradigm with EVs as 'sustainable inputs' that contribute to curbing energy consumption and harmful emissions." [98].

\subsection{Theoretical Framing of E-Mobility in a Circular Economy}

The scientific literature theorizing the CE of urban mobility is rather limited despite the need to transform to low carbon and economically feasible mobility systems [99-101]. By studying several European countries, Wijkman and Skånberg [102] suggest that if a nation's GDP is fully shifted to a CE, GHG emissions would reduce by $70 \%$ and the workforce would grow by $4 \%$. A fully CE as postulated by the Ellen MacArthur Foundation (EMAF) turns goods after their life into new resources for other goods, closing material and energy loops [21]. Some studies on the CE of e-mobility distinguish four strands that differentiate between the circularity of mobility and the circularity of material flow $[103,104]$. The CE as a triple bottom line approach analyzes the life cycle of different e-mobility technologies, assessing the ecological impact of products and treating economic feasibility and lifecycle (e.g., EV batteries) as its critical components [105,106]. Another strand theorizes the CE of mobility technologies in use: rather than focusing on mobility as a product provided by EV or ICE, it focuses on the mobility service it delivers [107]. A third strand concerns e-mobility as networked into the smart grid and other environmental technologies and infrastructures $[73,108]$. A fourth perspective spatializes the CE of mobility, focusing on mobility as moving across space and its ecological impacts [109]. Theoretical and practical e-mobility studies consider consumer practices, overall mobility experiences, and the possible acceptance of e-mobility solutions [110]. Although hardly invoked in the transport sector, the CE lens holds principles that may spur low carbon mobility transition. From system thinking, Grindsted [111] suggests that the higher the amount of energy, the shorter the system's lifecycle, and the higher the volume of materials used to provide a given service the less efficient and economically feasible it is in a CE frame. The notion of the CE acknowledges materials as assets to be preserved rather than consumed and focuses on services instead of products.

The above-mentioned four principles presuppose that a CE is present when a given service, such as mobility, is designed to provide the same or better service (efficiency) while the following indicators near zero: (1) energy use, (2) use of materials, (3) waste, (4) open and linear energy and material cycles [111]. Based on these presumptions, we suggest adding two more principles to the CE of mobility: (5) shorter distances, and (6) greater use of the mobility technology to uphold the service. The thermodynamics of any mobility service and its design within a CE should reflect the above principles. Interestingly, the EMAF [21] considers cars and light commercial vehicles in mobility but not their ecological impact. While buses, metros, trams, and other public transportation modes do not close the material cycles as the CE mobility perspective suggests (according to the principles above), selling mobility services, not material goods, with a reduced ecological impact (e.g., $\mathrm{CO}_{2}$ emissions) can provide a given service no matter the mobility pattern [112].

Laurischkat et al. [52] suggested that V2G business models will provide extra revenue for battery owners via the connection of EVs to the grid with at least a share of mobility consumers becoming energy prosumers. Mobility prosumers improve the e-mobility solution, according to the CE model. Denmark, the UK, the Netherlands, Germany, France, the USA, and Japan all have ongoing trials and demonstration research projects on this, so the exploration of economic and regulatory (including legal, in terms of energy trading taxes and peer-to-peer approaches) business models is expected soon [113]. 


\subsection{Energy Efficiency, Vehicle Design, and Battery Management}

A recent report of laboratory tests showed that the average $\mathrm{CO}_{2}$ emission of new cars sold in the EU in 2017 was 118.5 g per kilometer $(\mathrm{g} / \mathrm{km})$ of $\mathrm{CO}_{2}, 0.4 \mathrm{~g} / \mathrm{km}$ higher than in 2016 [82]. The average emissions remained below the current target of $130 \mathrm{~g} / \mathrm{km}$, which has existed since 2015. Since monitoring began in 2010, the mean emissions of new cars in the EU have dropped by $22 \mathrm{~g} / \mathrm{km}$ of $\mathrm{CO}_{2}$, a $15.5 \%$ decrease. Car producers must lower emissions very significantly to meet the EU target of $95 \mathrm{~g} \mathrm{CO}_{2} / \mathrm{km}$ by 2021 . The average $\mathrm{CO}_{2}$ emission of new vans sold in the EU in 2017 was $156.1 \mathrm{~g} / \mathrm{km}, 7.5 \mathrm{~g} / \mathrm{km}$ less than in 2016, and below the 2017 target of $175 \mathrm{~g} \mathrm{CO}_{2} / \mathrm{km}$. Van emissions must be cut further to reach the $2020 \mathrm{EU}$ target of $147 \mathrm{~g} \mathrm{CO}_{2} / \mathrm{km} \mathrm{[51].}$

According to the International Council on Clean Transportation (ICCT) report [96] (ICCT 2017), whilst 2016 figures in the EU indicate approximately $70 \mathrm{~g} / \mathrm{km} \mathrm{CO}_{2}$ emissions from EVs on average (dependent on the energy input), there are higher $\mathrm{CO}_{2}$ emission levels in HEVs $(91 \mathrm{~g} / \mathrm{km})$ and light commercial vehicles $(162 \mathrm{~g} / \mathrm{km})$. Energy efficiency in $\mathrm{BEVs} / \mathrm{PHEVs}$ depends on vehicle design and the battery and energy management, influencing the total cost of ownership over time. With more work around battery degradation and more focus on design and environmental internalized costs, EVs should see a break-even point [114]. Kreyenberg [115] explored the alternative power trains with a focus on electric batteries and fuel cells in Germany and found that private users' preferences regarding a middle-range car in complex interaction with legal and fiscal national instruments suggest that an upscaling of sales volume did not seem possible without public policy support in the short term.

Different cars have similar infrastructural land use, significantly higher compared to e-bicycle mobility. The smaller the loop, the more efficient a CE preserves physical stock, but the more inefficient it is in overcoming long distances [103]. The loop enlarges as CE investments and economic activity increase. The circular model of mobility focuses on the use of mobility as a service to minimize the circulation of materials. The EMAF [21] suggests that the world's transport sector accounts for $40 \%$ of the global iron demand. The steel-intensive automotive manufacturing industry should better design vehicles for closed material loops, since $25 \%$ of the material input for a new car consists of recycled materials, but $85 \%$ is down-cycled to other products when a car ends its life [21].

\subsection{Service-Based Mobility Solutions: Shared Assets, Shared Solutions}

As vehicles in the EU have an average lifetime of 16-17 years (eight years for commercial vehicles), closed material loops would extend their lifetime [96]. Additionally, CE Principles 5 and 6 suggest minimizing materials by also applying a system perspective in designing mobility services as part of the entire transport system, with a few materials and cycles as closed as possible to provide the service. A CE model of mobility following Stahel's [103] accounts value per weight rather than GDP. Cities have long examined car-sharing as the solution to urban mobility but have not found it to be a widely realistic strategy so far. ICT allows for new mobility services and urban digital business models to have a direct effect on issues of mobility partners, inter-modality, and transportation choices [54]. Car-sharing models that frame mobility as a service rather than a product partly challenge the linear economy of mobility (EV car ownership) by selling mobility as a service, not as a good [112]. Since cars are predominantly still organized as goods, they stand still $95 \%$ of the time, which is enormously inefficient by CE principles [111]. Mobility as a Service (MaaS) provides urban citizens with mobility without the need for ownership of the assets [116-118], which can be cars and infrastructures (among others) by transforming the e-car fleet into a network of e-car-sharing solutions so that many passengers can use the same asset under CE Principle 6 [52]. This can be distributed or from fixed points.

This produces quasi-private-public transportation in which e-mobility and car-sharing services have the benefit of optimizing the service of a vehicle provider through peersharing, which goes beyond the relationship between customer and company, making 
costumers the prosumers of mobility [112]. Results from Helsinki's Whim project suggest that users of MaaS use public transportation much more than their counterparts, replacing $38 \%$ of daily car commuting $[117,118]$. Users can become multi-modal and are then better at overcoming the first-mile problem. Public e-mobility should be the backbone of a CE model of e-mobility, where land-use inefficiency and the energy/material inefficiency shrink when converting EVs into shared and service-based mobility solutions [112].

A joint Cities and Regions for Transport Innovation-European Parking Association (POLIS-EPA) discussion paper on parking and urban development notes that there is a shift in focus from technology-digitization-to sustainable urban planning that is based on public and shared, temporary use of vehicles with new mobility services such as ride-hailing and micro-mobility $[119,120]$. Parking management technology should inform decision-makers about mobility and urban planning, including moving away from a mobility system based on large numbers of privately owned stationary cars. A discussion paper on micro-mobility notes this as a hot topic (including around e-scooters and ebikes) for local politicians and transport planners [121]. Not developing a proactive and consultative census may mean missing strategic opportunities.

Kopp [122] finds empirical evidence that in Germany, car-sharing is a mobility solution with prospects of decreasing urbanization costs. Car-sharing is seen as a viable tool to address substantial environmental and economic mobility issues as demonstrated by the Green Move project in Milan [123]. Gender is also a social dimension that should be explored. In Berlin, a survey indicated that electric car-sharing users are more often (middleaged) men with high education and income and likely to have full-time employment, while female early adopters used battery electric vehicles (BEVs) more often than ICE vehicles, evaluated the handling of BEVs as more positive, and showed a higher bike affinity and lower affinities towards technology and innovation compared to male respondents [124]. Women combined public transportation and bicycling with the use of (electric) car-sharing services as an additional part of urban mobility. The fundamental changes needed in urban mobility for environmental/health, socioeconomic, and digitalization reasons bring real chances to organize even complex (and inter-modal) mobility concept efficiency, increasing their social acceptance [125]. Such is the message of the contributions to future mobility in different formats from the DVWG [126].

\subsection{Drivers of and Barriers to E-Mobility in a Circular Economy}

From a meta-study perspective, Rezvani et al. [127] find that "drivers for EV adoption include pro-environmental attitudes, symbolic meanings, identity, and emotions, purchase cost of EVs is found to be a barrier to adoption while the lower running cost is shown to be a driver, hands-on experience with EVs changed attitudes to a large extent, yet the negative evaluation of range did not change, joy, pride and positive emotions from driving an EV and environmental concerns positively influence adoption intentions." Environmental concerns to lessen the contribution of transportation to GHG emissions, which in 2017 was $27 \%$ of total EU-28 GHG emissions (22\% if international aviation and maritime emissions are excluded) [82], are motivating factors for the transition to e-mobility in Europe [128]. EU countries and coalitions such as the Platform for Electromobility are pushing for incentives to achieve their targets of $\mathrm{CO}_{2}$ emissions reduction through policies around e-mobility and smart cities that rely on RE [129]. In 2017, the GHG emissions from the transport sector from the EU member countries were 946 million metric tons, $72 \%$ of which was from road transport, out of which $44 \%$ and $9 \%$ came from cars and light commercial vehicles, respectively [82]. From 1990-2017, Iceland recorded the highest $(142 \%)$ increase in GHG emissions from the transport sector among the major adopters of e-mobility in Europe, almost double that of Finland (78.6\%) and Austria (78.4\%) as the next highest countries. In contrast, Sweden achieved a 5\% reduction in its GHG emissions from transport within the same period. E-mobility can help reduce air pollution from GHG emissions, given that nearly $90 \%$ of the residents in EU cities are subjected to harmful air pollutants [128]. Moreover, e-mobility needs a more holistic business model for its 
widespread adoption [130]. The developing literature on Circular Economy business models, with an increasing emphasis on praxis framing, should be considered from now on to future-proof them [131-136]. Solar panels, for instance, also need a circular economy framing and a practical system for them [137]. Exploring differentiated and locally suited pathways to degrees of energy autonomy [138] can include e-mobility in a systems mix. Exploring the issues "only" through a sustainability (environmental, economic, and social pillars) lens can reveal blind spots, which a Circular Economy framing and perspective can help to address for the future. The CE in the EU is only partly developed currently and has much further and deeper to go [139]. This could then trigger shifts towards a "virtuous cycle" [140].

\section{Conclusions}

Clean transport solutions such as e-mobility powered by RE are being promoted by public authorities worldwide. E-mobility presents technological and behavioral challenges and opportunities for systems governance at organizational, household, and individual levels. The technological challenges include the EV use category, the sizing of the electric battery, how it is recharged, how the EV is integrated into a smart grid via ICT as well as smart mobility via Intelligent Transport Solutions, and V2G-enabled capability. Overcoming the challenges includes using EVs to support the energy infrastructure by smart charging and enabled bidirectional charging with (service and mobility) design and CE principles.

Charging EVs from distributed local RE is being piloted by supplying EV charging stations with local RE (beyond just supplying the energy to maintain or light the installation itself). Solar carports powered by an energy storing device for locally generated RE (though losses need considering) or EV charging with RE from the central grid (at low prices of electricity) is possible. This involves the use of Smart Grid concepts to optimize energy flow, which can be bidirectional, further engaging the consumers and making them active prosumers.

As for the future, with technical improvements to more electric-driven transportation technology, EVs will play an important role, especially in urban mobility. However, the circular economy perspective has only taken an early hold on the automotive as well as the e-mobility industry. This should change, and there is a need to further the integration of circular economy principles to mobility, as well as to e-mobility. A deep framing of e-mobility through CE principles, such as advocated here, can bring many environmental and social transformational benefits for inter-modal-connected and modal-shift-oriented urban mobility.

Author Contributions: Conceptualization, W.L.F; methodology, Y.A.A.; formal analysis, I.R.A., R.K., T.S.G., A.-L.B. and A.L.S.; investigation, W.L.F., I.R.A., R.K., T.S.G., A.-L.B., A.L.S., and Y.A.A.; writing-original, W.L.F., I.R.A., R.K., T.S.G., A.-L.B., A.L.S., and Y.A.A.; writing-review and editing, W.L.F., I.R.A., R.K., T.S.G., A.-L.B., A.L.S., Y.A.A., and F.W.; supervision, W.L.F. and I.R.A. All authors have read and agreed to the published version of the manuscript.

Funding: This study received no external funding.

Institutional Review Board Statement: Not applicable.

Informed Consent Statement: Not applicable.

Data Availability Statement: This is a review article, and no data were reported.

Conflicts of Interest: The authors declare no conflict of interest.

\section{References}

1. European Commission. Mobility and Transport. Electric Vehicles. Available online: https://ec.europa.eu/transport/themes/ urban/vehicles/road/electric_en (accessed on 21 May 2021).

2. Van Bree, B.; Verbong, G.P.; Kramer, G.J. A multi-level perspective on the introduction of hydrogen and battery-electric vehicles. Technol. Forecast. Soc. Chang. 2010, 77, 529-540. [CrossRef] 
3. Willing, C.; Brandt, T.; Neumann, D. Intermodal mobility. Bus. Inf. Syst. Eng. 2017, 59, 173-179. [CrossRef]

4. Hasan, M.A.; Abubakar, I.R.; Rahman, S.M.; Aina, Y.A.; Chowdhury, M.M.I.; Khondaker, A.N. The synergy between climate change policies and national development goals: Implications for sustainability. J. Clean. Prod. 2020, 249, 119369. [CrossRef]

5. Kester, J.; Sovacool, B.K.; Noel, L.; de Rubens, G.Z. Rethinking the spatiality of Nordic electric vehicles and their popularity in urban environment: Moving beyond the city? J. Transp. Geogr. 2020, 82, 102557. [CrossRef]

6. RAC (Royal Automobile Club). Are Electric Cars Really Better for the Environment? 12 June 2020. Available online: https: //www.rac.co.uk/drive/advice/emissions/are-electric-cars-actually-worse-for-the-environment/ (accessed on 21 May 2021).

7. Coppola, P.; Arsenio, E. Driving societal changes towards an electromobility future. Eur. Transp. Res. Rev. 2015, 7, 37. [CrossRef]

8. CEID (Circular Economy Initiative Deutschland). Resource-Efficient Battery Life Cycles: Driving Electric Mobility with the Circular Economy; Acatec/SYSTEMIQ/Circular Economy Initiative Deutschlandk: Berlin, Germany, 2020.

9. EEA (European Environment Agency). Electric Vehicles in Europe; European Energy Agency: Copenhagen, Denmark, 2016.

10. Emilsson, E.; Dahllöf, L. Lithium-Ion Battery and Vehicle Production. Status 2019 on Energy Use, CO2 Emissions, Use of Metals, Products' Environmental Footprint, and Recycling; IVL Swedish Environmental Research Institute: Stockholm, Sweden, 2019.

11. Regett, A.; Wagner, U.; Mauch, W.; Bangoj, J. Environmental Impact of Electric Vehicles: Potential of the Circular Economy? In Der Antrieb von Morgen; Leibl, J., Ed.; Springer: Wiesbaden, Germany, 2019; pp. 121-140.

12. Anderson, T.K. Electric Vehicles in Danish Municipalities. Vehicles 2019, 1, 4. [CrossRef]

13. Wurster, S.; Heß, P.; Nauruschat, M.; Jütting, M. Sustainable Circular Mobility: User-Integrated Innovation and Specifics and Electric Vehicle Owners. Sustainability 2020, 12, 7900. [CrossRef]

14. Wurster, S.; Schulze, R. Consumers' Acceptance of a Bio-circular Automotive Economy: Explanatory Model and Influence Factor. Sustainability 2020, 12, 2186. [CrossRef]

15. Reichmuth, R. Are Electric Vehicles Really Better for the Climate? 2020. Available online: https://blog.ucsusa.org/davereichmuth/are-electric-vehicles-really-better-for-the-climate-yes-heres-why (accessed on 21 May 2021).

16. MyGridGB. Last 12 Months, MyGridGB. May 2020. Available online: http://www.mygridgb.co.uk/last-12-months/ (accessed on 21 May 2021).

17. Hoekstra, A. The Underestimated Potential of Battery Electric Vehicles to Reduce Emissions. Joule 2019, 3, 1412-1414. [CrossRef]

18. E-ON. E-ON Sustainability Report. 2017. Available online: https://www.eon.com/content/dam/eon/eon-com/Documents/en/ sustainability-report/EON_Sustainability_Report_2017.pdf (accessed on 21 May 2021).

19. Chowdhury, M.M.I.; Rahman, S.M.; Abubakar, I.R.; Aina, Y.A.; Hasan, M.A.; Khondaker, A.N. A review of policies and initiatives for climate change mitigation and environmental sustainability in Bangladesh. Environ. Dev. Sustain. 2021, 23, 1133-1161. [CrossRef]

20. IPCC (Intergovernmental Panel on Climate Change). Global Warming of $1.5^{\circ} \mathrm{C}$; IPCC: Geneva, Switzerland, 2018.

21. UN News. Taking Fast Road to 'E-Mobility' Central to a Sustainable Future: COP24. 2018. Available online: https://news.un. org/en/story/2018/12/1027811 (accessed on 21 May 2021).

22. Schroeder, P.; Anngraeni, K.; Weber, U. The Relevance of Circular Economy Practices to the Sustainable Development Goals. J. Ind. Ecol. 2018, 23, 77-95. [CrossRef]

23. Umweltbundesamt [German Federal Environmental Agency]. 9 Principles for a Circular Economy; UBA: Dessau, Germany, 2020. Available online: https:/ / www.umweltbundesamt.de/sites/default/files/medien/1410/publikationen/2020_10_23_leitlinie_ kreislaufwirtschaft_englisch_bf.pdf (accessed on 21 May 2021).

24. BSR Electric. Electric Checklist for Municipalities, Local and National Politicians: E-Vans and E-Logistics. 11 June 2020. Available online: https:/ / www.bsr-electric.eu/content/7-results/bsr-electric-checklist-e-vans-and-e-logistics_final_june-11-2020.pdf (accessed on 21 May 2021).

25. Kotter, R.; Herteleer, B.; Asanova, R.; Van den Hoed, R.; Dong, J.; Putrus, G.; O’Brien, G.; Jablonska, B. SEEV4-City Policy Recommendations and Roadmap: Recommendations towards Integration of Transport, Urban Planning and Energy. Final Report. 2020. Available online: https:/ / www.seev4-city.eu/wp-content/uploads/2020/09/SEEV4-City-Policy-Recommendations-andRoadmap-1.pdf (accessed on 21 May 2021).

26. Abubakar, I.R.; Aina, Y.A. The prospects and challenges of developing more inclusive, safe, resilient and sustainable cities in Nigeria. Land Use Policy 2019, 87, 104105. [CrossRef]

27. Lajunen, A. Lifecycle costs and charging requirements of electric buses with different charging methods. J. Clean. Prod. 2018, 172, 56-67. [CrossRef]

28. Mahmoud, M.; Garnett, R.; Ferguson, M.; Kanaroglou, P. Electric buses: A review of alternative powertrains. Renew. Sustain. Energy Rev. 2016, 62, 673-684. [CrossRef]

29. Behrendt, F. Why cycling matters for e4plectric mobility: Towards diverse, active and sustainable e-mobilities. Mobilities 2018, 13, 64-80. [CrossRef]

30. Jones, T.; Harms, L.; Heinen, E. Motives, perceptions and experiences of electric bicycle owners and implications for health, wellbeing and mobility. J. Transp. Geogr. 2016, 53, 41-49. [CrossRef]

31. Kroesen, M. To what extent do e-bikes substitute travel by other modes? Transp. Res. Part D 2017, 53, 377-387. [CrossRef]

32. Le Bris, J. Pedelecs as New Tools for Active Mobility. In sustainability in Metropolitan Regions; Wulfhorst, G., Klug, S., Eds.; Springer: Wiesbaden, Germany, 2016. 
33. van Boven, J.F.; Le An, P.; Kirenga, B.J.; Chavannes, N.H. Electric scooters: Batteries in the battle against ambient air pollution? Lancet Planet. Health 2017, 1, e168-e169. [CrossRef]

34. Wahnschafft, R.; Wolter, F. Environmental Sustainability of City Sightseeing Cruises: A Case Study on Battery-Powered Electric Boats in Berlin, Germany. In Sustainable Transport and Tourism Destinations; Emerald Publishing: Bingley, UK, 2021.

35. Anderson, O.B.; Hansen, M.R.; Pedersen, H.C.; Conrad, F. Regeneration of Potential Energy in Hydraulic Forklift Trucks. In Proceedings of the 6th International Conference on Fluid Power Transmission and Control, Huangzhou, China, 5-8 April 2005.

36. Schäfer, P.K.; Blättel-Mink, B.; Hermenau, U.; Schmidt, K.; Lanzendorf, M.; Tandler, M.; Knese, D.; Buchsbaum, M.; Hermann, A.; Dalichau, D.; et al. Sozialwissenschaftliche Begleitforschung in Der Modellregion Elektromobilität Rhein Main; Frankfurt a.M.UoASand Goethe University: Frankfurt, Germany, 2015.

37. Van Mierlo, J.; Maggetto, G.; Lataire, P. Which energy source for road transport in the future? A comparison of battery, hybrid and fuel cell vehicles. Energy Convers. Manag. 2006, 47, 2748-2760. [CrossRef]

38. BSR Electric. Urban Logistics. Available online: https:/ / www.bsr-electric.eu/use-cases/urban-logistics (accessed on 27 May 2021).

39. Rupprecht Consult. Guidelines for Developing and Implementing A Sustainable Urban Mobility Plan, 2nd ed.; Rupprecht ConsultForschung \& Beratung GmbH: Köln, Germany, 2019. Available online: https://www.eltis.org/sites/default/files/sump_ guidelines_2019_interactive_document_1.pdf (accessed on 21 May 2021).

40. ELTIS. SUMP Online Guidelines. 15 June 2020. Available online: https://www.eltis.org/mobility-plans/sump-online-guidelines (accessed on 21 May 2021).

41. Lanzendorf, M.; Hebsacker, J. Mobilität 2.0.; Springer: Wiesbaden, Germany, 2017.

42. Rid, W.; Parzinger, G.; Grausam, M.; Müller, U.; Herdtle, C. Carsharing in Deutschland; Springer: Wiesbaden, Germany, 2017.

43. Mouli, G.R.; Vanduijsen, P.; Velzeboer, T.; Nair, G.; Zhao, Y.; Jamodkar, A.; Isabella, O.; Silvester, S.; Bauer, P.; Zeman, M. Solar Powered E-Bike Charging Station with AC, DC and Contactless Charging. In Proceedings of the 20th European Conference on Power Electronics and Applications, Riga, Latvia, 17-21 September 2018.

44. Apostolou, G.; Reinders, A.; Geurs, K. An Overview of Existing Experiences with Solar-Powered E-bikes. Energies 2018, 11, 2129. [CrossRef]

45. BSR Electric. Action Checklist for Municipalities and Companies: E-Bikes. May 2020. Available online: https://www.bsr-electric. eu/content/5-use-cases/e-bikes-for-commuters/bsr-electric-checklist-e-bikes.pdf (accessed on 28 May 2021).

46. Lambert, F. All-Electric Ferry Cuts Emission by $95 \%$ and Costs by 80\%, Brings in 53 Additional Orders. Electrek 2018. Available online: https:/ / electrek.co/2018/02/03/all-electric-ferry-cuts-emission-cost/ (accessed on 3 May 2021).

47. Lambert, F. Two Massive Ferries Are about to Become the Biggest All-Electric Ships in the World. Electrek 2017. Available online: https: / / electrek.co/2017/08/24/all-electric-ferries-abb/ (accessed on 21 May 2021).

48. Harris, A. Newsletter. Plug Boats. 11 February 2020. Available online: https:/ / plugboats.com/all-electric-passenger-ferry-forholiday-town/ (accessed on 21 May 2021).

49. BSR Electric. Action Checklist for Municipalities: E-Ferries. 11 June 2020. Available online: https://www.bsr-electric.eu/content/ 5-use-cases/e-ferries/bsr-electric-checklist-e-ferries_final_june-11-2020.pdf (accessed on 28 May 2021).

50. Bauer, C.; Cox, B.; Heck, T.; Hirschberg, S.; Hofer, J.; Schenler, W.; Simons, A.; Del Duce, A.; Althaus, H.J.; Georges, G.; et al. Opportunities and challenges for electric mobility—an interdisciplinary assessment of passenger vehicles. In Final Report of the THELMA Project in Co-Operation with the SWISS Competence Centre for Energy Research; ETH Zurich: Zürich, Switzerland, 2016.

51. European Commission. Slight Increase in Average CO2 Emissions from New Cars Sold in Europe in 2017, While CO2 Emissions from New Vans Continue to Decrease. European Commission. 4 April 2019. Available online: https://ec.europa.eu/clima/ news/slight-increase-average-co2-emissions-new-cars-sold-europe-2017-while-co2-emissions-new-vans_en (accessed on 27 May 2021).

52. Laurischkat, K.; Viertelhausen, A.; Jandt, D. Business models for electric mobility. Procedia CIRP 2016, 47, 483-488. [CrossRef]

53. Rietmann, N.; Lieven, T. How policy measures succeeded to promote electric mobility. J. Clean. Prod. 2019, 206, 66-75. [CrossRef]

54. Burmeister, K.; Rodenhäuser, B. Stadt Als System; Oekom: Munich, Germany, 2016.

55. Canzler, W.; Knie, A. Mobility in the age of digital modernity. Appl. Mobilities 2016, 1, 56-67. [CrossRef]

56. Nykvist, B.; Nilsson, M. The EV paradox. Environ. Innov. Soc. Transit. 2015, 14, 26-44. [CrossRef]

57. Van den Hoed, R.; Van der Hoogt, J.; Jablonska, B.; Van Bergen, E.; Arumugam, R.P.R.; Putrus, G.; Kotter, R.; Das, R.; Wang, Y.; Van den Hoed, R.; et al. Lessons Learnt-A cross-case analysis of six, real-time Smart Charging and V2X Operational Pilots in the North Sea Region. In Proceedings of the 32nd Electric Vehicle Symposium, Lyon, France, 19-22 May 2019.

58. Kester, J.; Noel, L.; de Rubens, G.Z.; Sovacool, B.K. Policy incentives to accelerate electric vehicle adoption. Renew. Sustain. Energy Rev. 2018, 94, 719-731. [CrossRef]

59. Kotilainen, K.; Aalto, P.; Valta, J.; Rautiainen, A.; Kojo, M.; Sovacool, B.K. From path dependence to policy mixes for Nordic electric mobility. Policy Sci. 2019, 52, 573-600. [CrossRef]

60. Kester, J.; Noel, L.; de Rubens, G.Z.; Sovacool, B.K. Promoting Vehicle to Grid (V2G) in the Nordic region. Energy Policy 2018, 116, 422-432. [CrossRef]

61. IEA (International Energy Agency). Global EV Outlook 2019; International Energy Agency: Paris, France, 2019. 
62. European Federation for Transport and Environment AISBL. Transport \& Environment Report. January 2020. Available online: https:/ / www.transportenvironment.org/sites/te/files/publications /01\%202020\%20Draft\%20TE\%20Infrastructure\% 20Report\%20Final.pdf (accessed on 28 May 2021).

63. Tames, M.; Van den Hoed, R. Moving a Taxi Sector to Become Electric: Characterizing Taxi Drivers Interested in Purchasing a Full Electric Vehicle. World Electr. Veh. J. 2020, 11, 20. [CrossRef]

64. Asanova, S.; Ribeiro, C.; Kotter, R.; Putrus, G.; Dong, J. SEEV4-City Policy Recommendations. EU Interreg North Sea Region. 2020. Available online: https://www.seev4-city.eu/wp-content/uploads/2020/09/SEEV4-City-Project-Policy-Recommendations.pdf (accessed on 21 May 2021).

65. Van Bergen, E.; Van der Hoogt, J.; Kotter, R.; Bentley, E.; Warmerdam, J.; Rimmer, C.; Herteleer, B.; van Bergen, E.; van der Hoogt, J.; Kotter, R.; et al. Vehicle4 Energy Services (V4ES): Evaluation for Upscaling and Transnational potential. SEEV4-City Final Report. 2020. Available online: https:/ /www.seev4-city.eu/wp-content/uploads/2020/11/V4ES-Evaluation-for-Upscalingand-Transnational-Potential-Final-Report.pdf (accessed on 22 May 2021).

66. Competence Center for Energy Research "Efficient Technologies and Systems for Mobility"; ETH Zurich: Zürich, Switzerland, 2016.

67. Bühne, J.A.; Gruschwitz, D.; Hölscher, J.; Klötzke, M.; Kugler, U.; Schimeczek, C. How to promote electromobility for European car drivers? Eur. Transp. Res. Rev. 2015, 7, 30. [CrossRef]

68. Christensen, L.; Klauenberg, J.; Kveiborg, O.; Rudolph, C. Suitability of commercial transport for a shift to electric mobility with Denmark and Germany as use cases. Res. Transp. Econ. 2017, 64, 48-60. [CrossRef]

69. Cansino, J.M.; Sánchez-Braza, A.; Sanz-Díaz, T. Policy instruments to promote electro-mobility in the EU28: A comprehensive review. Sustainability 2018, 10, 2507. [CrossRef]

70. Kannan, P.; Hirschberg, S. Interplay between electromobility and transport sectors. Transport. Res. Part A 2016, 94, 514-531.

71. Biresselioglu, M.E.; Kaplan, M.D.; Yilmaz, B.K. Electric mobility in Europe: A comprehensive review of motivators and barriers in decision making processes. Electric mobility in Europe. Transp. Res. Part A 2018, 109, 1-13.

72. Codani, P.; Portz, P.L.L.; Claverie, P.; Petit, M.; Perez, Y. Coupling local renewable energy production with electric vehicle charging:a survey of the French case. Int. J. Automot. Technol. Manag. 2016, 16, 55-65. [CrossRef]

73. Friis, F. Integrating Smart Grid Solutions within Everyday Life; Aalborg University Press: Aalborg, Demark, 2016.

74. National Grid. Future Energy Systems. 2019. Available online: http:/ / fes.nationalgrid.com/media/1409/fes-2019.pdf (accessed on 21 May 2021).

75. Komarnicki, P.; Haubrock, J.; Styczynski, Z.A. Elektromobilität und Sektorenkoppelung; Springer: Wiesbaden, Germany, 2018.

76. Bretzke, W.-R. Nachhaltige Logistik, 3rd ed.; Springer: Wiesbaden, Germany, 2014.

77. Fojcik, T.M.; Proff, H. Accelerating market diffusion of battery electric vehicles through alternative mobility concepts. Int. J. Automot. Technol. Manag. 2014, 14, 347-368. [CrossRef]

78. European Commission. Implementing the Energy Performance of Building Directive 2016, Country Reports; European Commission: Brussels, Belgium, 2016.

79. Haddadian, G.; Khodayar, M.; Shahidehpour, M. Accelerating the global adoption of electric vehicles. Electr. J. 2015, 28 , 53-68.

80. Cames, M.; Helmers, E. Critical evaluation of the European diesel car boom-global comparison, environmental effects and various national strategies. Environ. Sci. Eur. 2013, 25, 1-22. [CrossRef]

81. ICCT (International Council on Clean Transportation). European Vehicle Market Statistics; ICCT: Washington, DC, USA, 2017.

82. EEA. Greenhouse Gas Emissions from Transport in Europe; EEA: Copenhagen, Denmark, 2019. Available online: https: / / www.eea.europa.eu/data-and-maps/indicators/transport-emissions-of-greenhouse-gases/transport-emissions-ofgreenhouse-gases-12 (accessed on 21 May 2021).

83. Mock, P.; Yang, Z. Driving Electrification; International Council on Clean Transportation: Washington, DC, USA, 2014.

84. European Alternative Fuels Observatory. Latest update in March 2020. Available online: https://www.eafo.eu/ (accessed on 12 May 2021).

85. Wesseling, J.H. Explaining variance in national electric vehicle policies. Environ. Innov. Soc. Transit. 2016, 21, 28-38. [CrossRef]

86. Van der Steen, M.; Van Schelven, R.M.; Van Deventer, P.; Van Twist, M.; Kotter, R. Policy strategies for an emergent technology: Lessons from the analysis of EV-policy in 8 North- European countries. World Electr. Veh. J. 2015, 7, 710-721. [CrossRef]

87. Augenstein, K. Analysing the potential for sustainable e-mobility. Environ. Innov. Soc. Transit. 2015, 14, 101-115. [CrossRef]

88. Gebauer, F.; Vilimek, R.; Keinath, A.; Carbon, C.C. Changing attitudes towards e-mobility by actively elaborating fast-charging technology. Technol. Forecast. Soc. Chang. 2016, 106, 31-36. [CrossRef]

89. Cansino, J.M.; Yñiguez, R. Promoting electro mobility in Spain. Public measures and main data (2007-2012). Transp. Res. Part D Transp. Environ. 2018, 59, 325-345. [CrossRef]

90. Netherlands Enterprise Agency. Electric Transport in The Netherlands. Highlights 2017; Netherlands Enterprise Agency: The Hague, The Netherlands, 2018.

91. Figenbaum, E. Norway-The world leader in BEV adoption. In Who's Driving Electric Cars? Contestabile, M., Tal, G., Turrentine, T., Eds.; Springer: Cham, Switzerland, 2020; pp. 89-120.

92. Lieven, T. Policy measures to promote electric mobility. Transp. Res. A 2015, 82, 78-93.

93. WRAP. Electrical \& Electronic Sustainability Action Plan (esap); WRAP: Banbury, UK, 2015. Available online: https://wrap.org.uk/ resources/guide/electricals/electrical-electronic-sustainability-action-plan (accessed on 27 May 2021). 
94. Walcher, D.; Leube, M. Kreislaufwirtschaft in Design and Produktmanagement: Co-Creation Im Zentrum der Zirkulären Wertschöpfung; Springer: Wiesbaden, Germany, 2017.

95. Capgemini Research Institute. The Automotive Industry in the Era of Sustainability. 2020. Available online: https://www. capgemini.com/wp-content/uploads/2020/03/Report-The-automotive-industry-in-the-era-of-sustainability.pdf (accessed on 21 May 2021).

96. Karagoz, S.; Aydin, N.; Simic, V. End-of-life vehicle management: A comprehensive review. J. Mater. Cycles Waste Manag. 2020, 22, 416-442. [CrossRef]

97. Konietzko, J.; Bocken, N.; Hultink, E.J. Circular ecosystem innovation: An initial set of principles. J. Clean. Prod. 2020, $253,119942$. [CrossRef]

98. ENEL. Available online: https://corporate.enel.it/en/circular-economy-sustainable-future/electric-mobility (accessed on 21 March 2020).

99. Abubakar, I.R.; Bununu, Y.A. Low carbon city: Strategies and case studies. In Sustainable Cities and Communities. Encyclopedia of Sustainability in Higher Education; Springer: Cham, Switzerland, 2020; pp. 366-376.

100. Hardman, S.; Chandan, A.; Tal, G.; Turrentine, T. The effectiveness of financial incentives for Battery Electric Vehicles. Renew. Sustain. Energy Rev. 2017, 80, 1100-1111. [CrossRef]

101. Watson, M. How theories of practice can inform transition to a decarbonised transport system. J. Transp. Geogr. 2012, 24, 488-496. [CrossRef]

102. Wijkman, A.; Skånberg, K. Circular Economy and Benefits from Society; Club of Rome: Winterthur, Switzerland, 2015.

103. Stahel, W.R. The circular economy. Nature 2016, 53, 1435-1438. [CrossRef]

104. Korhonen, J.; Honkasalob, A.; Seppäläc, J. Circular Economy. Ecol. Econ. 2018, 143, 37-46. [CrossRef]

105. EEA639. Electric Vehicles from Life Cycle and Circular Economy Perspectives. TERM 2018: Transport and Environment Reporting Mechanism (TERM) Report; EEA report No. 13/2018; EEA: Copenhagen, Denmark, 2018.

106. Groenewald, J.; Grandjean, T.; Marco, J. Accelerated energy capacity measurement of lithium-ion cells to support future circular economy strategies for electric vehicles. Renew. Sustain. Energy Rev. 2017, 69, 98-111. [CrossRef]

107. Weetman, C. A Circular Economy Handbook for Business and Supply Chains: Repair, Remake, Redesign, Rethink; Kogan Page: London, UK, 2016.

108. Jittrapirom, P.; Caiati, V.; Feneri, A.M.; Ebrahimigharehbaghi, S.; Alonso González, M.J.; Narayan, J. Mobility as a service: A critical review of definitions, assessments of schemes, and key challenges. Urban Plan. 2017, 2, 13-25. [CrossRef]

109. Strengers, Y. Smart Energy Technologies in Everyday Life-Smart Utopia? Palgrave Macmillan: London, UK, 2013.

110. Yigitcanlar, T.; Dur, F. Developing a Sustainability Assessment Model: The Sustainable Infrastructure, Land-Use, Environment and Transport Model. Sustainability 2010, 2, 321-340. [CrossRef]

111. Grindsted, T.S. Hvad er energi og miljøinnovation. In Klimaledelse; Born-Rasmussen, E., Ed.; Forlaget Andersen: Copenhagen, Denmark, 2019.

112. Utriainen, R.; Pöllänen, M. Review on mobility as a service in scientific publications. Res. Transp. Bus. Manag. 2018, 27, 15-23. [CrossRef]

113. Noel, L.; de Rubens, G.Z.; Kester, J.; Sovacool, B.K. Vehicle-to-Grid; Palgrave Macmillan: London, UK, 2019.

114. Conti, M.; Kotter, R.; Putrus, G. Energy Efficiency in Electric and Plug-in Hybrid Electric Vehicles and Its Impact on Total Cost of Ownership. In Electric Vehicle Business Models; Beeton, D., Meyer, G., Eds.; Springer: Cham, Switzerland, 2015.

115. Kreyenberg, D. Fahrzeugantriebe für die Elektromobilität; Springer: Wiesbaden, Germany, 2016.

116. Casals, L.C.; García, B.A.; Cremades, L.V. Electric vehicle battery reuse: Preparing for a second life. J. Ind. Eng. Manag. 2017, 10, 266-285. [CrossRef]

117. International Association of Public Transport (UITP). Mobility as a Service. Report. April 2019. Available online: https: / / www.uitp.org/sites/default/files/cck-focus-papers-files/Report_MaaS_final.pdf (accessed on 27 May 2021).

118. Rambøll. Whimpact Insights from the World's First Mobility-As-A-Service (Maas) System. 2019. Available online: https://maasalliance.eu/whimpact-insights-from-the-worlds-first-mobility-as-a-service-maas-system/ (accessed on 21 May 2021).

119. POLIS Network. Polis Paper-Parking and Urban Development. POLIS Network. 25 November 2019. Available online: https: / / www.polisnetwork.eu/document/polis-parking-paper-2019/ (accessed on 27 May 2021).

120. POLIS Network. Polis Paper-Macro Managing Micro Mobility. POLIS Network. 27 November 2019. Available online: https: //www.polisnetwork.eu/document/macromanaging-micromobility/ (accessed on 12 May 2021).

121. TransportXtra. Insight into new mobility services: New EU report. 19 March 2020. Available online: https://www.transportxtra. com/publications/local-transport-today/news/64754/insight-into-new-mobility-services-new-eu-report/ (accessed on 27 May 2021).

122. Kopp, J. Success Factors for Future Growth of Car Sharing Services; Springer: Wiesbaden, Germany, 2020.

123. Bignami, D.F.; Vitale, A.C.; Lué, A.; Nocerino, R.; Rossi, M.; Savaresi, S.M. Electric Vehicle Sharing Services for Smarter Cities; Springer: Cham, Switzerland, 2018.

124. Kawgan-Kagan, I. Early adopters of carsharing with and without BEVs with respect to gender preferences. Eur. Transp. Res. Rev. 2015, 7, 33. [CrossRef]

125. Anthrakidis, A.; Jahn, R.; Ritz, T.; Schöttler, M.; Wallenborn, R.; Warmke, G. Urbanes eCarSharing in einer vernetzten Gesellschaft; Steinbeis-Edition: Stuttgart, Germany, 2013. 
126. Deutsche VerkehrsWissenschaftliche Gesellschaft (DVWG). Neue Formen der Mobilität. J. für Mobilität und Verkehr $2019,2$.

127. Rezvani, Z.; Jansson, J.; Bodin, J. Advances in consumer electric vehicle adoption research. Transp. Res. Part D 2015, 34, 122-136. [CrossRef]

128. Pietrzak, K.; Pietrzak, O. Environmental Effects of Electromobility in a Sustainable Urban Public Transport. Sustainability 2020, 12, 1052. [CrossRef]

129. POLIS Network. Calls for Auto Industry Support to Be Tied to Climate Action. POLIS Network. 8 April 2020. Available online: http:/ / www.polisnetwork.eu/news/calls-for-support-for-auto-industry-to-be-tied-to-action-on-climate/ (accessed on 27 May 2021).

130. Kley, F.; Lerch, C.; Dallinger, D. New business models for electric cars. Energy Policy 2011, 39, 3392-3403. [CrossRef]

131. De Angelis, R. Business Models in the Circular Economy: Concepts, Examples, and Theory; Palgrave: London, UK, 2018.

132. Lacey, P.; Long, J.; Spindler, W. The Circular Economy Handbook; Palgrave Macmillan: London, UK, 2020.

133. Frodermann, L. Exploratory Study on Circular Economy Approaches; Springer: Wiesbaden, Germany, 2018.

134. Wiesmeth, H. Implementing the Circular Economy for Sustainable Development. Elsevier: Dordrecht, The Netherlands, 2020.

135. Mavropolous, A.; Nilson, A.W. Industry 4.0 and Circular Economy: Towards a Wasteless Future or a Wasteful Planet? Wiley/International Solid Waste Association: Chichester, UK, 2020.

136. Santibanez Gonzalez, E.D.; Koh, L.; Leung, J. Towards a circular economy production system: Trends and challenges for operations management. Int. J. Prod. Res. 2019, 57, 7209-7218. [CrossRef]

137. Dirr, M. Strategische Planung eines Kreislaufwirtschaftssystems für Photovoltaikmodule; Springer: Wiesbaden, Germany, 2016.

138. Bentley, E.; Kotter, R.; Wang, Y.; Das, R.; Putrus, G.; Van Der Hoogt, J.; Van Bergen, E.; Warmerdam, J.; Heller, R.; Jablonska, B. Pathways to energy autonomy-challenges and opportunities. Int. J. Environ. Stud. 2019, 76, 893-921. [CrossRef]

139. Eisenriegler, S. Kreislaufwirtschaft in der EU. Eine Zwischenbilanz; Springer: Wiesbaden, Germany, 2020.

140. MacArthur, E. The Virtuous Cycle; “Big Idea” Essay. European Investment Bank, 2018. Available online: https://www.eib.org/en/ essays/the-virtuous-circle (accessed on 21 May 2021). 